\title{
Monoligual Health? Linguistic Barriers in Slovene Healthcare Experienced by Migrant/Refugee Women
}

\author{
Uršula Lipovec Čebron \\ University of Ljubljana, Slovenia \\ ursula.lipovec@ff.uni-lj.si \\ Lea Bombač \\ University Medical Centre Ljubljana, Slovenia \\ bombac.lea@gmail.com \\ Nike Kocijančič Pokorn \\ University of Ljubljana, Slovenia \\ nike.pokorn@ff.uni-lj.si \\ Miha Lučovnik \\ University Medical Centre Ljubljana, Slovenia \\ mihalucovnik@yahoo.com
}

The aim of the article is to identify the main obstacles related to the language barriers that arise between migrants/refugee patients and healthcare personnel in the field of gynecology and obstetrics. To identify these obstacles a qualitative research was conducted from May 2017 to June 2018 among migrant/refugees and healthcare workers in Slovenia. The results show that first, linguistic obstacles are often the consequence of the lack of available professional healthcare interpreters/intercultural mediators; second, the absence of training of medical personnel on linguistic dimensions of healthcare causes inadequate awareness of interpreter's/intercultural mediator's role; and third, the linguistic obstacles that migrant/refugee women face hinder their access to basic health rights, entitlements and limitations, including reproductive rights. These obstacles significantly impair the ability of Slovene healthcare system to establish quality communication with migrant/refugee women and may cause inequalities among foreign-speaking healthcare users in their access to healthcare.

\section{Introduction}

European population is becoming increasingly diverse, not only due to the presence of migrants and refugees, but also because of a growing number of other people on the move (e.g. tourists, truck-drivers, business people or exchange students etc.). In this situation 'the idea of diversity has radically changed to include other dimensions of diversity such as immigration status, 
gradations in rights and entitlements, migration history, and socioeconomic status' (Chiarenza, 2014). Besides other areas of society, also healthcare sector is compelled to respond to a multiple-diversity needs as individual needs are expressed by the intersection of differences such as origin, class, gender, age, language, and other social distinctions (Yuval-Davis, 2006).

As previous research in Slovenia has shown (Bofulin \& Bešter, 2010; Farkaš, 2016; Bombač et al., 2017; Kocijančič Pokorn \& Lipovec Čebron, in press), healthcare institutions are slow to respond to the presence of increasingly diverse population. As a result, non-Slovene citizens living in this country face a series of obstacles when searching for health. Since legal, administrative and socio-cultural barriers in healthcare were already extensively addressed in other studies (Brovč, Ahčin, Šlajpah, \& Rotar-Pavlič, 2009; Jazbinšek-Palaić, 2009; Bofulin \& Bešter, 2010; Lipovec-Čebron, 2010a, 2010b; Lipovec Čebron et al., 2016; Bombač et al., 2017; Lipovec Čebron \& Pistotnik, 2015, 2018), in this chapter we will attempt to identify the main linguistic obstacles in providing patient care for migrant/refugee women in Slovenia.

A nation-wide survey of healthcare workers in Slovenia ( $n=564$, healthcare workers, incl. physicians, dentists, and nurses) on communication between healthcare workers in Slovene healthcare system and non-Slovenespeaking (NSSP) or limited Slovene proficient patients (LSPP) has shown that language diversity poses a great challenge to healthcare personnel to ensure quality healthcare (Kocijančič Pokorn \& Lipovec Čebron, in press). The results of this survey have shown that $94 \%$ of respondents have contacts with foreign-speaking patients in their work, and that the most challenging encounters are those with Albanian-speaking patients and with patients who speak Arab, Chinese, Russian, Roma and other languages. The same survey has also shown that communication problems arise in various medical fields, however, that they are most common in emergency services, family medicine, paediatrics, and obstetrics/gynecology. ${ }^{1}$ Moreover, health problems or diagnoses that are most frequent among users who do not speak Slovene fell in the following categories: first, antenatal, perinatal and postnatal care; second, injuries; third, psychiatric problems; fourth, gastrointestinal problems and fifth, respiratory infections etc. (Mikolič Južnič, in press).

\footnotetext{
${ }^{1}$ In the survey, the respondents were asked to indicate medical fields where they encounter most problems in communication with non-Slovene-speaking patients. Twelve medical fields were provided on the list and the respondents were able to add additional ones if they wanted. The majority of respondents (67\%) selected emergency services (and $27 \%$ emergency transportation related services). The second most frequently selected medical field was family medicine $(56 \%)$, followed by pediatrics $(34 \%)$, gynecology $(28 \%)$ and obstetrics $(24 \%)$.
} 
Since the medical field of gynecology and obstetrics was identified as one of the areas where linguistic barriers are most commonly present, we focus here on the analysis of the crucial linguistic barriers encountered by migrant/refugee women in search for gynecological/obstetric medical help. The analysis is based on qualitative research conducted from May 2017 to June 2018 among migrants/refugees ${ }^{2}$ with whom we conducted four semistructured interviews in different locations in Ljubljana and one focus group with six women residing in the reception center (Asylum seeker center). Since our interlocutors ${ }^{3}$ were native speakers of Arab and Farsi, interviews and the focus group discussion were translated from Farsi and Arab. Moreover, in the chapter we also present experiences of healthcare personnel of different profiles ${ }^{4}$ collected during two focus groups discussions of linguistic and cultural aspects of healthcare. The first focus group was organized in one of Slovene healthcare centers, where 12 healthcare workers participated; the second was held in two maternity hospitals in Slovenia, where 15 healthcare workers altogether collaborated. These healthcare institutions were chosen because they cater for a higher number of foreign-speaking users compared to other healthcare institutions in Slovenia. The interviews and the focus group discussions were transcribed, the material was classified according to different thematic areas and later analyzed. These findings are combined with findings of previous research on health aspects of migration (Lipovec Čebron, 2010a, 2010b, 2011; Lipovec Čebron \& Pistotnik, 2015, 2018, in press; Bombač et al., 2017). On the basis of our research we identified three levels of obstacles that are connected with language barriers and are presented in the following pages.

\section{Absence of Interpreters/Intercultural Mediators}

Unlike in some other countries of the European Union, Slovene healthcare does not have a national system of professional interpreting service avail-

\footnotetext{
${ }^{2}$ In the chapter we use both terms: 'migrant' as well as 'refugee' since we do not want to reproduce the problematic dichotomy between the 'economic migrant' and 'refugee' that was recently misused in xenophobic and racist anti-immigration political propaganda across Europe.

${ }^{3}$ All of our interlocutors were pregnant or had recently given birth; their age ranged from 20 to 30 years; six of ten interlocutors were asylum seekers, while other four were persons with recognised international protection. Due to the sensibility of the topic, we keep their other data anonymised.

${ }^{4}$ Their profiles were: 8 nurses, 4 general practitioners, 15 specialists and fellows in gynecology and obstetrics. Due to the sensibility of the topic, we keep the institutions anonymised.
} 
able in healthcare institutions. ${ }^{5}$ Although many professional interpreters exist, they lack the training for interpreting in healthcare setting, are often difficult to reach and their services are too expensive for an average patient (Lipovec Čebron \& Bombač, in press). This problem was addressed also in the document Country Report for Slovenia: 'Even though the Patient Rights Act (ZpacP) includes the patient's right to understand the procedure, to be informed and not to be discriminated against, in practice there is a great lack of systematic solutions (national or regional policy) regarding the availability of interpretation services.' (MIPEX, 2015 p. 19). The lack of available interpretation services is causing a series of consequences, as it is clear from the fragments of the interviews:

Tania gave birth in Slovenia. When asked what her birth experience in Slovenia was like, she answered: 'Nothing good. [...] I feel pain, I ask the doctor for caesari, doctor said "No. No." I do not know why. I say, I want. And doctor: "No, no." I do not understand why not. They gave 2 tablets at midnight. At 14 o'clock very painful. Then injection, then with a needle [artificial rupture of membranes, AN]. Then 20 hours, of pain, pain.' [Interview with Tania, Ljubljana, 18. 10. 2017]

The interview shows that she did not understand the procedure inducing labor and could not get the information why the physician refused to do caesarean section. She therefore felt maltreated and thought that this was because she was a refugee. Due to language problems, she was deprived of the right to autonomously decide on the course of childbirth, methods of pain relief during labor, and agree or disagree with utilized medical procedures.

During delivery [...] I could not explain to a woman in labor what was going on or give her instructions. Another day a foreign woman came to my office but I could not explain to her what was going on well enough because it would had taken me a lot more time since she spoke only a few Slovene and English words. But if she was accompanied by a female interpreter who would understand the language well, it would all be much easier! [Focus group in the maternity hospital, 11. 10. 2017]

The above responses of the interviewees show that the absence of interpreter or intercultural mediator is, on one hand, causing unsatisfactory expe-

\footnotetext{
${ }^{5}$ For instance, in Italy, Germany or Switzerland (Gosenca, 2017).

${ }^{6}$ All Slovene utterances were translated into English by Uršula Lipovec Čebron.
} 
rience in medical setting for migrant/refugee women who felt that her patient's rights were violated. On the other hand, they reveal how the absence of interpretation services is creating difficult situation for medical personnel who cannot perform their work in a professional and competent manner. In addition, the second example shows that overcoming language barriers adds additional strain since it is time consuming and often results in medical personnel not communicating effectively with the patient. Previous research (Gorjanc, 2013; Gosenca, 2017; Milavec Kapun et al., 2017; Rotar Pavlič et al., 2017; Kocijančič Pokorn \& Lipovec Čebron, in press) has shown that linguistic barriers are one of the crucial factors that limit the access to healthcare institutions for migrant population in Slovenia. The consequences of these barriers are multifold: from avoiding or delaying the visit to the doctor, to numerous misunderstandings or even traumatic experiences in medical settings.

These findings are in line with research in other countries (Bowen, 2001; Angelelli, 2008; Schapira et al., 2008; Verrept, 2008; Ingleby, Chiarenza, DEville, \& Kotsioni, 2012) that demonstrate that absence of or lack of quality interpretation and translation in healthcare constitutes not only violations of basic healthcare standards and poses a risk to the patients' safety, but also creates a significant financial burden for the healthcare system (Kocijančič Pokorn, in press).

The lack of systematic support leads to situations where patients as well as healthcare workers are left to their own inventiveness in their attempts to address communication obstacles, as the following case shows:

A young woman from Kosovo speaking only Albanian in her last week of pregnancy came to maternity hospital. She was accompanied by her husband and their five-year-old daughter. Due to the lack of amniotic liquid I suggested to induce labor the following day and described the method, but I noticed that her husband did not understand me well. Finally, I explained it with the following words: 'Baby has no water, so he can no longer swim, this is why he has to come out soon. I suggest your wife gives birth tomorrow. Please, translate it to her. He translated it to his wife with few words, and she started telling him something with a worried expression on her face. When I finally asked him to translate, he did it in a single sentence telling me that she was only surprised a little bit. He probably noticed my surprise and quickly added: 'You know, you Slovenes sometimes have hundred words, while we have just one.' [Focus group in the maternity hospital, 6. 6. 2018] 
The described situation shows how the patient's husband was inadequately interpreting due to his limited language skills and his unfamiliarity with medical terminology and maybe also due to some other reasons unknown to the healthcare worker. In order to respond to language barriers, friends, relatives or other acquaintances often step in the role of nonprofessional (ad-hoc) interpreters. As previous research has shown (Schapira et al., 2008; Bofulin et al., 2016), ad-hoc interpreters are more available, familiar and less expensive than professional interpreters, but at the same time they provide less reliable interpretation (they can interpret inaccurately, omitting and adding information), do not respect confidentiality of data and may contribute to many errors and miscommunication in medical settings. One of the wide-spread practices, also in Slovenia, is to assign to a child who accompanies his parents to medical examination the role of ad-hoc interpreter, as the following experience demonstrates:

When you treat patients speaking only Arabic, Albanian, Chinese ... It may happen that a mother comes with her daughter who speaks fluently Slovene: what to do? You ask the daughter to translate. My colleagues do it, I do it, nobody says it is wrong. But once there was a problematic situation: should a decision to abort be translated by a child to her mother? When I was going home I asked myself: what if my child was translating for me? I felt bad and after that I tried to find other solutions when I needed translation. [Focus group in the healthcare center, 5. 8. 2017]

As gynecologist's experience illustrates, the common practice to engage children in interpretation was not seen problematic by her co-workers. However, she began to question this practice and decided to abandon it. Unlike in Slovenia, in some other countries it is explicitly prohibited the use of children for these purposes (e.g. in the US state of California), since children in the role of interpreters could be exposed to stressful and traumatic experiences while interpreting about sensitive and delicate matters (for example, family violence, psychiatric illnesses, sexually transmitted diseases, abortion, terminal illnesses) (Kocijančič Pokorn, in press).

Besides using ad-hoc interpreters, there are other strategies adopted by medical personnel in Slovenia to facilitate the communication with foreignspeaking patients. The results of the already mentioned nation-wide survey has shown that the most commonly used strategy in the Slovene healthcare system is the use of lingua franca - a language of communication that is 
not a native language of either of communication participants (House, 2003). The survey has shown that Slovene healthcare workers usually use English (global lingua franca) and Croatian/Serbian/Bosnian/Montenegrin (regional lingua franca). This strategy is followed by the use of ad-hoc interpreters and by communication with mimics and gestures. To a lesser degree, Slovene health professionals ask for help their colleagues who know the language of the healthcare user. Quite often they also practice intercomprehension, i.e. practice when each speaker speaks their first language and assumes that their meanings will be understood by the other interlocutor (cf. House 2015, p. 101). It is also common to use online dictionaries and translators (such as, for example, Google Translate). However, all described strategies should be seen as temporary and provisional solutions, since they cannot guarantee accurate communication and cannot replace professional interpreter or intercultural mediator (Kocijančič Pokorn, in press).

\section{Lack of Training on Language Aspects of Healthcare}

Considering the fact that communication with patients who do not speak foreign languages was for decades systematically neglected in Slovenia, it is not surprising that health professionals are not well acquainted with linguistic aspects of healthcare provision. As our interlocutors emphasized, during their studies (at medical faculties and faculties of health sciences) as well as during their professional careers, there was no specific training that would prepare healthcare personnel for a work in a culturally and ethnically diverse healthcare setting. ${ }^{7}$

Interlocutor 1: All you have said [about cultural and linguistic aspects of healthcare, AN] is fine, but I don't know where to look for an interpreter.

\footnotetext{
${ }^{7}$ In last years some project-based initiatives are attempting to bridge this gap, e.g. by organizing a 2o-hours cultural competency training in three community health centres (in the city of Celje, Sevnica and Vrhnika) by National institute for public health in the framework of the project 'Together for health' (http://www.nijz.si/sl/publikacije/ucni-nacrt-usposabljanje -za-razvijanje-kulturnih-kompetenc-zdravstvenih-delavcev) as well as 11 similar trainings in the framework of the project 'MoST' (http://www.nijz.si/sl/most-model-skupnostnega-pristopa-za -krepitev-zdravja-in-zmanjsevanje-neenakosti-v-zdravju-v-lokalnih). Moreover, a specific training for healthcare workers on communication with foreign-speaking patients was organized in different Slovene cities as a part of the project 'Designing a Multilingual Aid for Better Communication of Migrants with Healthcare Personnel' (http://multilingualhealth.ff.uni-lj.si/). Just recently a summer school with the title 'Cultural Competences, Doctor-Patient Communication, and Minority Health' has been organized for students from different European medical faculties (http://www.mf.uni-lj.si/media-library/2018/02/22d71f322ddoebb69df169918dfc14C7_1.pdf).
} 
Interlocutor 2: Yes, I would also like to have an interpreter, especially for Albanian women, but how to get one? Nobody told us anything about this.

Interlocutor 1: No, nobody ... we didn't get any information that this is so important.

Researcher: What about during your studies?

Interlocutor 1: No, I don't remember that we have ever mentioned this [focus group in the healthcare center, 5. 8. 2017]

An Albanian-speaking woman came to the maternity hospital with her husband to induce labor. I suggested that I invite a female interpreter to attend the labor and she agreed to it. Therefore, I informed a senior doctor that her husband does not understand Slovene well and is not planning to assist the childbirth if not necessary, since, according to him, childbirth is a female thing, besides he has to work in another city. I suggested to medical personnel that we call a professional interpreter to come to help us in communication. Surprisingly, I was answered that her husband knows Slovene well enough to interpret and that we will call him when we need him. However, only few weeks ago we received information at the hospital that we could call an Albanian female interpreter for free, so I contacted her. She was willing to come to the hospital whenever we wanted, so I went to tell this to a midwife, print this interpreter's contacts and stuck it on the walls in different rooms for medical staff. Just before I left delivery room, I heard the midwife asking the patients' husband how they say 'push' in Albanian; when he answered, she repeated after him and wrote it down. Few hours later I come back to the delivery room, hearing baby crying and two women chatting in a foreign language. Well, midwife decided to call the interpreter and reported that woman in labor got so relaxed that the baby went out quicker than expected. The midwife, however, just in case tried to learn a word in Albanian to help the woman in labor. Besides, she wanted not only to understand the woman but also to be understood well, this is why she called the interpreter [Focus group in the maternity hospital, 6. 6. 2018]

The last case shows that besides insensitivity to different understandings of gender roles (husband did not want to participate at labor since he perceives the childbirth to be a 'female thing'), there exists a lack of knowledge about the importance of quality interpretation. Although the interpreter was 
available and free of charge for the patient, medical personnel was unwilling to contact her. Contrary to that, the midwife understood the significance of engaging the interpreter and even showed respect towards patient's native language by learning some basic words. Similar attitude is present among many other healthcare workers that show an increased interest in collaborating with interpreters/intercultural mediators as the already mentioned national survey demonstrates. For example, the most frequent answer $(n=$ 271 out of 564) to the question 'What would help you bridging linguistic and other barriers when dealing with users who do not speak Slovene?' was: 'the introduction of interpreters/intercultural mediators' ${ }^{8}$ (Lipovec Čebron, in press). ${ }^{9}$

\section{Lack of Information on Healthcare Rights}

Lack of information on patient rights, organization of healthcare system and use of health service can be seen as general problem among migrants/refugees with different legal statuses in Slovenia (Bofulin \& Bešter, 2010 p. 272). The problem that migrant population is not adequately informed was raised also in the Country report for Slovenia: 'Lack of information about entitlements is a serious barrier to exercising them: people who do not know their rights cannot claim them. [...] This situation is made worse when legislation is complex and changes rapidly. There is no systematic dissemination of information concerning entitlements and use of health service for the migrant population. [...] However, since the information is difficult to find, access to it depends on personal initiative and motivation.' (MIPEX, 2015 p. 17). Similar conclusions are found in a quantitative research on health of mi-

\footnotetext{
${ }^{8}$ The others suggested information support in the form of mobile applications and online translation tools and the multilingual handbook for basic medical treatment as well as the training in the field of cultural competences.

${ }^{9}$ Not only should healthcare workers be aware of the importance of interpreters/intercultural mediators in healthcare setting, they should also be trained to successfully collaborate with them: 'Simple recommendations for working effectively with interpreters include the need to warn the interpreter prior to the meeting if sensitive information will be discussed and a proper introduction of the interpreter to the patient that promotes collegiality and delineates roles and expectations. All parties should be positioned so that the clinician and patient can maintain proper eye contact throughout the interview, and, finally, both the physician and interpreter should use short phrases devoid of jargon. Asking the patient to repeat what he or she has understood, and having the interpreter "back translate" the content, provides an additional tool to check the accuracy of translation as well as the patient's understanding (B. Lubrano, R. Brown, C. Bylund, et al., personal communication)' (Schapira et al., 2008). For more information see Kocijančič Pokorn and Lipovec Čebron (in press) and International Medical Interpreters Association (2017).
} 
grant/refugee women with various legal statuses in Slovenia (Kulovec, 2012), which demonstrates that almost one fifth of the surveyed migrants/refugees (18.5\% out of 63 ) did not receive any information about their health rights (Kulovec, 2012 p. 31). The accurate information on health system is even more difficult to reach in cases when women live in isolation (e.g. in Detention centre in Postojna) or are marginalized from general society (Asylum seeker centers in Vič or Logatec).

Also interviews conducted in the focus group in the Asylum seeker center have shown that asylum seekers who participated in the focus group were unfamiliar with their reproductive rights:

They were highly motivated to talk about their experiences with giving birth and had many questions on reproductive rights and how to solve different gynecological and other medical problems [...] All women had little or no information on contraception, they did not know how to get it, what forms of contraception are available in Slovenia and what kind of contraception is available free of charge. Most of them were not informed that they can get free condoms from a social worker who works in the asylum center, in the same department as they were located [Notes from focus group in the Asylum seeker center, 18. 10. 2017]

The fact that refugees/migrants do not receive adequate healthcare information could be the result of different factors (social isolation, dissimilarity of healthcare systems in different countries, different legal and social statuses, education etc.) (Bofulin \& Bešter, 2010; Lipovec Čebron \& Bombač, in press). However, one of the most important factors is the linguistic barrier which numerous migrants/refugees who do not speak the Slovene language experience when searching for information on Slovene healthcare system. In this regard one of the recurrent assumptions shared by healthcare workers in Slovenia is that migrant/refugees do not make enough effort to understand and speak Slovene (Lipovec Čebron, in press). Contrary to these assumptions, a qualitative and quantitative research among asylum seekers in Ljubljana shows that this group of migrants has a very positive attitude towards the Slovene language and that all of the interviewed individuals who had been in Slovenia for 7 months or more, regardless of their level of educational, make an effort to learn Slovene by taking the statefunded course of Slovene. Nevertheless, the same research demonstrated that despite the fact that most asylum seekers learn Slovene very quickly or speak English, they need additional linguistic support in high-risk situations, 
for example when communicating with healthcare workers (Pokorn \& Čibej, 2018).

In the attempt to provide migrants/refugees in Slovenia with at least some basic information on healthcare in Slovenia, some project-based initiatives were carried out, and some ad-hoc brochures ${ }^{10}$ were translated in different languages (e.g. Albanian, Arabic, English, Pashtu, Persian, Russian, Tigrinya, Turkish, etc.) and mainly disseminated over websites. However, since this information is scattered across various webpages, those who are not fluent in Slovene might find it difficult to find. ${ }^{11}$

\section{Conclusions}

Looking at the Slovene healthcare system from a language perspective reveals that it is governed by a pronounced monolingual attitude. This is not evident only from the absence of interpreters/intercultural mediators, but also from different aspects of healthcare services: wayfinding signage system in healthcare institutions, various forms (e.g. informed consent, diagnoses or referrals to specialist examinations) and information on patient's healthcare rights can be rarely found in any other languages besides Slovene. In contrast, patients who enter Slovene healthcare institutions are increasingly diverse, speak a multitude of languages that are unfamiliar to healthcare workers. In this almost 'monolingual healthcare system' where linguistic problems are not addressed at the systemic level, patients and healthcare workers are left to fend for themselves. As a result, many obstacles related to the language barriers arise between them.

On the basis of our research we identified three levels of obstacles that are connected with language barriers in the field of gynecology and obstetrics. Firstly, we analyzed some linguistic obstacles that are the consequence of the lack of available professional interpreters/intercultural mediators. Secondly, we showed that absence of medical personnel training on linguistic aspects of healthcare service provision leads to the fact that they are unaware of the importance of the support provided by qualified interpreter/intercultural mediators. Lastly, we demonstrated that language barriers faced by migrant/refugee women hinder them to exercise their basic patient rights, including reproductive rights. These obstacles significantly impair the ability of Slovene healthcare system to establish quality communication with migrant/refugee women and thus provide quality healthcare service, and

\footnotetext{
${ }^{10}$ See http://www.infotujci.si and http://www.nijz.si/sl/projekt-care.

${ }^{11}$ Moreover, the information is often unattainable for those who are illiterate.
} 
may cause inequalities among different healthcare users in their access to healthcare. On the basis of our research, we can conclude that due to the absence of systemic approach to address language issues, healthcare workers in Slovene healthcare system encounter many obstacles which often hinder them to provide high quality healthcare, while migrant/refugee women experience several difficulties when searching for it. Their traumatic experience in healthcare settings is probably best described by Ramin: 'Knowledge of language literally means the difference between paradise or hell.' (Petrovčič, 2018, p. 33).

\section{References}

Angelelli, C. (2008). The role of the interpreter in the healthcare setting: A plea for a dialogue between research and practice. In C. Valero-Garcés \& A. Martin (Ed), Crossing borders in community interpreting: Definitions and dilemmas (pp. 147-164). Amsterdam, The Netherlands: Benjamins.

Bofulin, M., \& Bešter, R. (2010). Enako zdravstvo za vse? Imigranti v slovenskem zdravstvenem sistemu. In M. Medvešek \& R. Bešter (Eds.), Državljani tretjih držav ali tretjerazredni državljani? (pp. 270-311). Ljubljana, Slovenia: Inštitut za narodnostna vprašanja.

Bofulin, M., Farkaš Lainščak, J., Gosenca, K., Jelenc, A., Keršič Svetel, M., Lipovec Čebron, U., Pistotnik, S., Škraban, Š., \& Zaviršek, D. (2016). Kulturne kompetence in zdravstvena oskrba: priročnik za razvijanje kulturnih kompetenc zdravstvenih delavcev. Ljubljana, Slovenia: Nacionalni inštitut za javno zdravje.

Bombač, L., Lipovec Čebron, U., Pistotnik, S., Turk Šverko, A., Trojar, A., Repar Bornšek, S., Sodja, N., Hadžiahmetović, A., Liberšar, H., \& Zelko, E. (2017). Zdravstvena obravnava prosilcev in prosilk za mednarodno zaščita v Sloveniji. In E. Zelko (Ed.), 10. Zadravčevi dnevi: zbornik predavanj (pp. 28-.36). Ljubljana, Slovenia: Zavod za razvoj družinske medicine.

Bowen, S. (2001). Language barriers in access to health care. Ottawa, Canada: Health Canada.

Brovč, M., Ahčin, J. Šlajpah, M., \& Rotar-Pavlič, D. (2009). Ekonomski imigranti v Sloveniji in njihova stališča o boleznih: kvalitativna raziskava. Zdravstveno varstvo, 48(1), 26-32.

Chiarenza, A. (Ed). (2014). Standards for equity in health care for migrants and other vulnerable groups: Self-assessment tool for pilot implementation. Reggio Emilia, Italy: Regional HPH Network of Emilia-Romagna.

Farkaš-Lainščak, J. (Ed.). (2016). Ocena potreb uporabnikov in izvajalcev preventivnih programov za odrasle: ključni izsledki kvalitativnih raziskav in stališča strokovnih delovnih skupin. Ljubljana, Slovenia: Nacionalni inštitut za javno zdravje.

Gorjanc, V. (2013). Tolmačenje za skupnost in vprašanje nadnacionalne odgov- 
ornosti. In V. Gorjanc (Ed.), Slovensko tolmačenje (pp. 120-133). Ljubljana, Slovenia: Znastvena založba Filozofske fakultete Univerze v Ljubljani.

Gosenca, K. (2017). Medkulturna mediacija: Priložnost za boljšo zdravstveno oskrbo. (Unpublished master's thesis). University of Ljubljana, Ljubljana, Slovenia.

House, J. (2003). English as a lingua franca: A threat to multilingualism? Journal of Sociolinguistics, $7(4), 556-578$.

House, J. (2015). Translation quality assessment: Past and present. London, England: Routledge.

Ingleby, D., Chiarenza, A., Deville, W., \& Kotsioni, I. (Ed.). (2012). Inequalities in health care for migrants and ethnic minorities (COST Series on Health and Diversity 2). Antwerp, The Netherlands: Garant Publishers.

International Medical Interpreters Association. (2017). Medical interpreting standards of practice. Retrieved from http://www.imiaweb.org/uploads/pages/ 102.pdf

Jazbinšek, S., \& Palaić, T. (2009). Zdravje - človekova pravica? Prosilke in prosilci za mednarodno zaščito. Časopis za kritiko znanosti, 37(238), 154-162.

Kocijančič Pokorn, N. (in press). Reševanje jezikovnih ovir v slovenskem zdravstvu: analiza stanja. In N. Kocijančič Pokorn \& U. Lipovec Čebron (Eds.), Večjezično zdravje: komunikacijske strategije in večkulturni stiki s tujezičnimi bolniki v slovenskem zdravstvenem sistemu. Ljubljana, Slovenia: Filozofska fakulteta.

Kocijančič Pokorn, N., \& Lipovec Čebron, U. (Eds.). (in press). Večjezično zdravje: komunikacijske strategije in večkulturni stiki s tujezičnimi bolnikiv slovenskem zdravstvenem sistemu. Ljubljana, Slovenia: Filozofska fakulteta.

Kulovec, J. (2012). Zdravje imigrantk v Sloveniji (Unpublished undergraduate thesis). University of Ljubljana, Ljubljana, Slovenia.

Lipovec Čebron, U. (2010a). The construction of a health uninsurant. People without medical citizenship as seen by some Slovene health workers. Studia ethnologica Croatica, 22, 187-212.

Lipovec Čebron, U. (2010b). Slepa pega evropskega zdravstva: analiza nekaterih vidikov zdravja migrantov. In K. Medica, G. Lukič, \& M. Bufon (Eds.), Migranti v Sloveniji: med integracijo in alienacijo (pp. 57-81). Koper, Slovenia: Annales.

Lipovec Čebron, U. (2011). Reformiranje zdravstvenega sistema Slovenije: med 'Iustracijskimi' in 'jugonostalgičnimi' težnjami. Etnolog, 21, 179-201.

Lipovec Čebron, U. (in press). Medkulturni (in drugi) nesporazumi v zdravstvu. In N. Kocijančič Pokorn \& U. Lipovec Čebron (Eds.), Večjezično zdravje: komunikacijske strategije in večkulturni stiki s tujezičnimi bolniki v slovenskem zdravstvenem sistemu. Ljubljana, Slovenia: Filozofska fakulteta.

Lipovec Čebron, U., Keršič-Svetel, M., \& Pistotnik, S. (2016). Zdravstveno marginalizirane - 'ranljive' skupine: ovire v dostopu do sistema zdravstvenega 
varstva in v njem. In J. Farkaš-Lainščak (Eds.), Ocena potreb uporabnikov in izvajalcev preventivnih programov za odrasle: ključni izsledki kvalitativnih raziskav in stališča strokovnih delovnih skupin (pp. 14-25). Ljubljana, Slovenia: Nacionalni inštitut za javno zdravje.

Lipovec Čebron, U., \& Bombač, L. (in press). Pregnant women on the move and the response of Slovenian health system to their needs. Glasnik Etnografskog instituta SANU.

Lipovec, U., \& Pistotnik, S. (2015). Iluzija o univerzalnem dostopu do zdravstvenega zavarovanja: nedržavljani, prekarni, revni kot zdravstveno nezavarovani prebivalci. Etnolog, 25, 89-111.

Lipovec Čebron, U., \& Pistotnik, S. (in press). Migrants/refugees in Slovene healthcare: Many open questions and some possible answers. In M. Rajković Iveta, P. Kelemen, \& D. Župarić-Iljić (Eds.), Contemporary migration trends and flows on the territory of Southeast Europe. Zagreb, Croatia: Filozofski fakultet u Zagrebu.

Lipovec Čebron, U., \& Pistotnik, S. (2018). (Im)mobile populations and health rights: Accessing the healthcare system in slovenia. In C. Vindriola-Padros, G., A. Johnson, \& A. E. Pfister (Eds.), Health and care (im)mobilities (pp. 53-73). New York, NY: Berghahn.

Mikolič Južnič, T. (2018). Kdo dela z uporabniki zdravstvenega sistema, ki ne govorijo slovensko? In N. Kocijančič Pokorn \& U. Lipovec Čebron (Eds.), Večjezično zdravje: komunikacijske strategije in večkulturni stiki s tujezičnimi bolniki v slovenskem zdravstvenem sistemu. Ljubljana, Slovenia: Filozofska fakulteta.

Milavec Kapun, M. Rotar-Pavlič, D., Lipovec Čebron, U. Kocijančič Pokorn, N., Pistotnik, P., Milavec Kapun, M., Hirci, N., Jelenc, A., \& Zelko, E. 2017. Strategije premagovanja jezikovnih ovir med medicinskimi sestrami. In S. Majcen Dvrošak, T. Štemberger Kolnik, \& A. Kvasa-Predoslje (Eds.), Medicinske sestre in babice - ključne za zdravstveni sistem: zbornik prispevkov z recenzijo; 11. Kongres zdravstvene in babiške nege Slovenije (pp. 564-573). Ljubljana, Slovenia: Zbornica zdravstvene in babiške nege Slovenije.

MIPEX. 2015. MIPEX-Country Report for EQUI-HEALTH. Brussels, Belgium: International Organisation for Migration.

Pokorn, N. K., \& Čibej, J. (2018). Interpreting and linguistic inclusion - friends or foes? Results from a field study. The Translator, 24(2), 111-127.

Rotar-Pavlič, D., Lipovec Čebron, U., Kocijančič Pokorn, N., Pistotnik, P., Milavec Kapun, M., Hirci, N., Jelenc, A., \& Zelko, E. (2017). Jezikovne ovire in kako jih presegati. Družinska medicina, 15(2), 12-15.

Petrovčič, P. (2018, 17 August). Ramin Shadani, begunec. Mladina, pp. 33-37.

Schapira, L., Vargas, E., Hidalgo, R., Brier, M., Sanchez, L., \& Hobrecker, L. (2008). Lost in translation: Integrating medical interpreters into the multidisciplinary team. The Oncologist, 13, 586-592. 
Verrept, H. (2008). Intercultural mediation: An answer to health care disparities? In C. Valero-Garcés, \& A. Martin (Eds.), Crossing borders in community interpreting: Definitions and dilemmas (pp. 187-201). Amsterdam, The Netherlands: Benjamins.

Yuval-Davis, N. (2006). Intersectionality and feminist politics. European Journal of Women's Studies, 13, 193-209.

S. Ličen, I. Karnjuš, \& M. Prosen (Eds.). (2019). Women, migrations and health: Ensuring transcultural healthcare (pp. 139-153).

Koper, Slovenia: University of Primorska Press.

https://doi.org/10.26493/978-961-7055-43-6.139-153 